\title{
Educational institutions as a field for speech-language-hearing research: an analysis of publications in brazilian journals
}

\author{
Luciana Figueiredo de Oliveira ${ }^{1}$ \\ https://orcid.org/0000-0003-1796-0318 \\ Ivonaldo Leidson Barbosa Lima² \\ https://orcid.org/0000-0003-1716-1575 \\ Brunna Thais Luckwu de Lucena ${ }^{1}$ \\ https://orcid.org/0000-0003-4179-6773 \\ Biatriz Lima do Nascimento ${ }^{3}$ \\ https://orcid.org/0000-0002-6998-6395 \\ Larissa Leite Filgueira ${ }^{3}$ \\ https://orcid.org/0000-0001-7530-6766 \\ Laura Ennay Correia Mendes ${ }^{3}$ \\ https://orcid.org/0000-0003-4096-5037 \\ Janaína von Söhsten Trigueiro ${ }^{1}$ \\ https://orcid.org/0000-0002-5958-1220
}

Universidade Federal da Paraíba - UFPB, Departamento de Fonoaudiologia, João Pessoa, Paraíba, Brasil.

Centro Universitário de João Pessoa Unipê, Departamento de Fonoaudiologia, João Pessoa, Paraíba, Brasil.

Universidade Federal da Paraíba - UFPB, Curso de Fonoaudiologia, João Pessoa, Paraíba, Brasil.

This paper was developed at the Departamento de Fonoaudiologia da Universidade Federal da Paraíba - UFPB, João Pessoa, Paraíba, Brasil.

Conflict of interests: Nonexistent

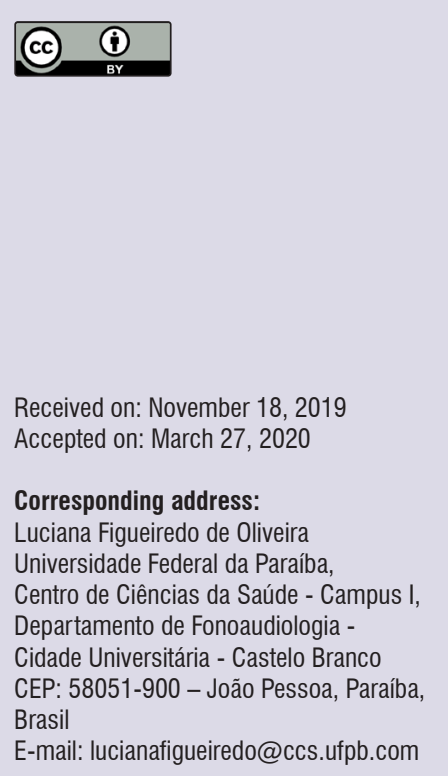

\section{ABSTRACT}

Purpose: to analyze and characterize the speech-language-hearing publications that have Brazilian educational institutions as their field.

Methods: all the national active and inactive speech-language-hearing journals were accessed to analyze the titles and abstracts of all articles that referred to research in educational institutions. Articles addressing speech-language-hearing issues, developed in educational institutions, and published in the journals analyzed were selected. The articles found were categorized and analyzed. The categories considered the journal of publication, year of publication, the speech-language-hearing field of knowledge they approached, research context/type of educational institution, target audience, and procedures conducted in the educational institutions. Then, a descriptive statistical analysis was carried out.

Results: the largest amount of research made in Brazilian educational institutions was published in CEFAC, in 2015. Such studies were mainly related to the field of language, most of them conducted with elementary school students, to collect data on their assessment and/or diagnosis.

Conclusion: national speech-language-hearing research conducted in educational institutions has privileged practices in the fields of language and voice, in elementary school, with students and teachers.

Keywords: Speech, Language, and Hearing Sciences; Education; School Health; Indicators; Review Literature as a Topic 


\section{INTRODUCTION}

From the very beginning, the speech-languagehearing (SLH) sciences have interacted with education, and the educational institutions have always been ground for working and researching in that field. A study ${ }^{1}$ on places privileged by SLH research observed that schools were its second largest field of investigation.

It is believed that when the Conselho Federal de Fonoaudiologia - CFFa (Federal Council of Speech Language Pathology and Audiology) through its resolution no. 387 from $2010^{2}$ regulated educational SLH therapy as one of its specialized branches, the development of studies in the context of education received an additional impulse. That document explains that an SLH therapist working in this context must focus on practices that encompass the teaching and learning process ${ }^{2}$. Thus, it is understood that an educational SLH therapist must have a broad field of action, considering all the singularities of the institution where they are located, encompassing aspects that go much beyond identifying, assessing and/or (re)habilitating specific communication disorders.

It cannot be overlooked that, besides educational SLH therapy, other branches in this field have legitimately used the educational context for their research. On the other hand, it must be considered that most of the professionals working in educational SLH therapy are not specialized in education, but other SLH specializations, despite the growing number and diversity of courses approaching an SLH therapist's work. Such factors can certainly influence the goals and objects of research conducted in Brazilian educational institutions ${ }^{3}$.

The development of scientific research points to the growth and expansion of knowledge produced by a specific field ${ }^{4}$. Hence, it is important to verify the national scientific production on SLH therapy, to observe and spread knowledge on the field and encourage more research to strengthen this specialty. In this sense, this research aimed to analyze and characterize the publications on SLH sciences conducted in Brazilian educational institutions.

\section{METHODS}

This integrative bibliographical research aimed to synthesize results obtained in research systematically, orderly and comprehensively conducted ${ }^{5}$.

Therefore, this study was developed to answer the following research question: What are the characteristics of the SLH research conducted in Brazilian educational institutions? To this end, four independent researchers carried out the bibliographical search in all existing national SLH journals in the Brazilian literature.

Firstly, all active and inactive journal volumes published online from 2011 to 2018 were selected this interval was defined because it corresponds to the establishment of educational SLH therapy as a specialty by the Conselho Federal de Fonoaudiologia (CFFa) ${ }^{2}$. After the volumes had been selected, each researcher individually analyzed them to identify published studies that referred to research conducted in Brazilian educational institutions

\section{Selection criteria}

To select the articles that would comprise this research's corpus, the following eligibility criteria were adopted:

- Having been published between 2011 and 2018 in an SLH scientific journal, either active or inactive, registered with a code in the International Standard Serial Number (ISSN);

- Dealing with SLH issues;

- Having Brazilian educational institutions as their research field.

In this selection, all the publications whose title and/ or abstract referred to SLH practices in Brazilian educational institutions were included.

Afterward, the selected articles' methodology was analyzed. In this stage, articles that did not deal with $\mathrm{SLH}$ issues, that were conducted in foreign educational institutions, that were based on databanks, or whose target audience was selected from attendance in clinics and/or hospitals were excluded. Moreover, literature reviews, thesis and dissertation abstracts, and articles without a clear methodology regarding their public audience selection and/or object of study were also excluded.

The number of articles excluded based on this analysis is shown in Figure 1. 
441 articles selected from reading their title and abstract

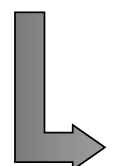

162 articles excluded for not being in line with the purpose of the research

279 articles that report speech-language-hearing research conducted in Brazilian educational institutions

Figure 1. Number of articles analyzed and excluded

\section{Data analysis}

To proceed to the data analysis, the articles found were categorized and analyzed according to these variables: (1) journal of publication; (2) year of publication; (3) SLH field of knowledge they approached; (4) research context/type of educational institution; (5) target audience; (6) procedures conducted in the educational institutions (EI). It is important to state that, during the process of selecting and analyzing the articles, all the divergences regarding the studies were solved through consensus among the four researchers.

Regarding the SLH specialty the studies approached, they were classified based on those established by the CFFa, as well as their definition and/ or field of action described in each specific resolution. As for the articles that fall into more than one specialty, an effort was made to distinguish the most prevalent one, based on the study's purpose, keywords, and results presented. In such cases, the articles were read in full. When it was not possible to define the prevailing specialty, the article was placed in the "interspecialty" category. Articles that interfaced between SLH and another science were named "multidisciplinary". Other articles were found that did not fall into any specific SLH specialty; instead, they dealt with teaching and/or training practices in SLH sciences. For these cases, the "teaching SLH sciences" category was created.

The data analysis was made with descriptive statistics techniques in the Statistical Package for Social Sciences (SPSS) software, version 20.0 for Windows.

\section{LITERATURE REVIEW}

The identification of journals, as well as the number of volumes and articles selected (Figure 2), indicate that most of the research conducted in Brazilian educational institutions was published in CEFAC. 


\begin{tabular}{|l|c|c|c|c|c|}
\hline Journal & Years & $\begin{array}{c}\text { Quantity of } \\
\text { numbers }\end{array}$ & $\begin{array}{c}\text { Number of } \\
\text { published } \\
\text { articles }\end{array}$ & $\begin{array}{c}\text { Number } \\
\text { of articles } \\
\text { selected }\end{array}$ & $\begin{array}{c}\text { Number } \\
\text { of articles } \\
\text { analyzed }\end{array}$ \\
\hline $\begin{array}{l}\text { Revista da Sociedade Brasileira de } \\
\text { Fonoaudiologia (RSBFa) }\end{array}$ & $2011-2012$ & 8 & 183 & 31 & 20 \\
\hline $\begin{array}{l}\text { Jornal da Sociedade Brasileira de } \\
\text { Fonoaudiologia (JSBFa) }\end{array}$ & $2011-2012$ & 8 & 130 & 17 & 15 \\
\hline CoDAS & $2013-2018$ & 36 & 550 & 112 & 51 \\
\hline Revista CEFAC & $2011-2018$ & 49 & 1190 & 153 & 106 \\
\hline Revista Distúrbios da Comunicação (DIC) & $2011-2018$ & 29 & 485 & 90 & 60 \\
\hline Audiology Communication Research (ACR) & $2013-2018$ & 15 & 292 & 38 & 27 \\
\hline Total & & 145 & 2830 & 441 & 279 \\
\hline
\end{tabular}

Figure 2. Listing of journals and articles analyzed

The values presented in the research conducted in Brazilian educational institutions published between 2011 and 2018 in the journals analyzed are presented in
Figure 3. They show a decrease in studies whose field of research are such institutions, beginning in 2016.

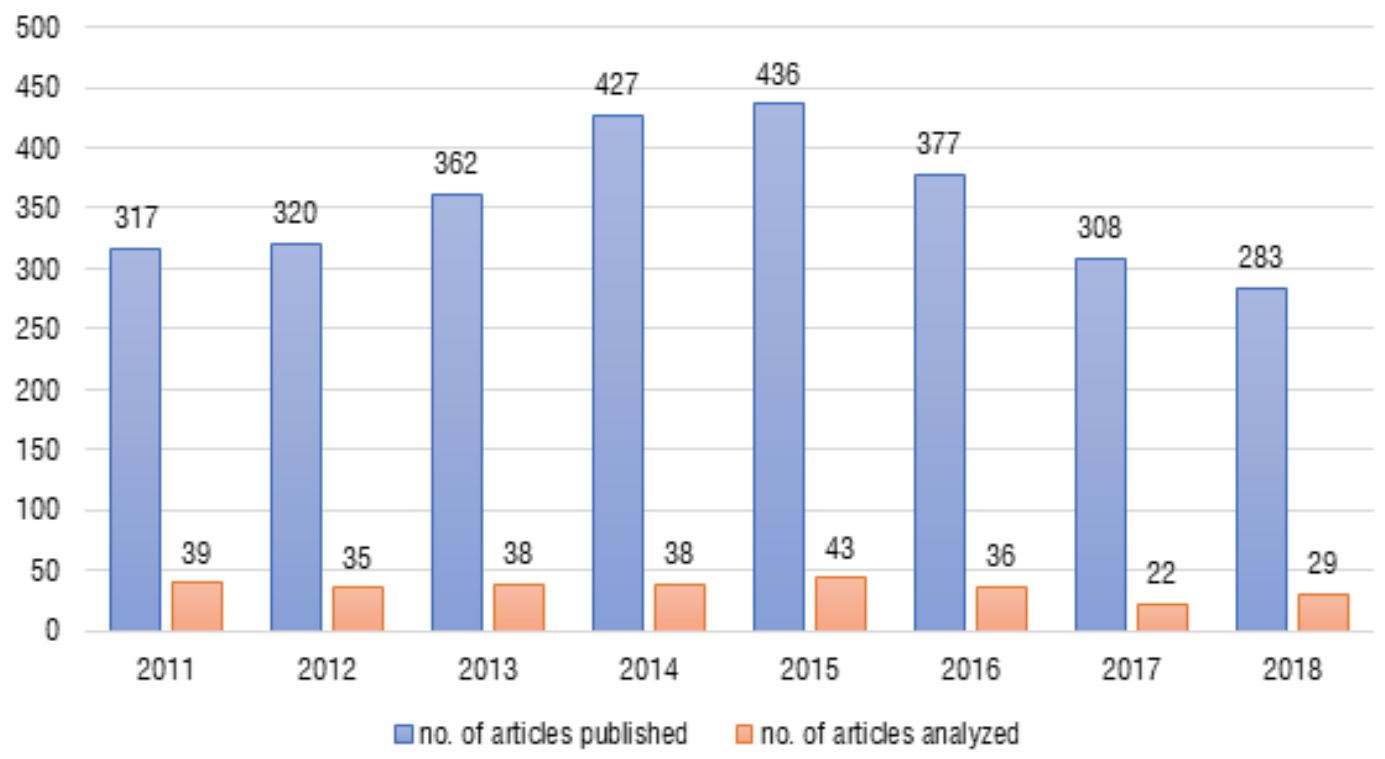

Figure 3. Number of articles published and analyzed by year

The distribution of articles by field shows that the great majority of the research conducted in Brazilian educational institutions is related to the field of language, followed by studies in the fields of voice and audiology. Studies connected to educational SLH therapy represent only $6.1 \%$ of the research (Table 1 ). 
Table 1. Number of publications per speech-language-hearing field

\begin{tabular}{lcc}
\hline FIELD & N & $\%$ \\
\hline Audiology & 38 & 13.6 \\
Teaching in speech-language-hearing & 5 & 1.8 \\
Fluency & 2 & 0.7 \\
Educational speech-language-hearing & 17 & 6.1 \\
Labor speech-language-hearing & 2 & 0.7 \\
Gerontology & 1 & 0.4 \\
Interspecialty & 4 & 1.4 \\
Language & 124 & 44.4 \\
Orofacial motor functions & 10 & 3.6 \\
Public health & 8 & 2.9 \\
Voice & 67 & 24 \\
Multidisciplinary & 1 & 0.4 \\
\hline TOTAL & 279 & 100 \\
\hline
\end{tabular}

It is noted that most of the studies conducted in an educational setting involve elementary or middle school, and only one dealt with vocational/adult education (Table 2). In most of the research, the target audience was students, followed by teachers. Only one, though, researched the administrative staff (Table 3).

Table 2. Number of publications per level of education

\begin{tabular}{lcc}
\hline EDUCATIONAL CONTEXT & N & $\%$ \\
\hline Preschool & 38 & 13.6 \\
Elementary and Middle School & 147 & 52.7 \\
High School & 7 & 2.5 \\
Higher Education & 37 & 13.3 \\
Special Education & 4 & 1.4 \\
Vocational/Adult Education & 1 & 0.4 \\
Mixed & 18 & 6.4 \\
Not specified & 27 & 9.7 \\
\hline TOTAL & 279 & 100 \\
\hline
\end{tabular}

Table 3. Number of publications, according to the target audience

\begin{tabular}{lcc}
\hline TARGET AUDIENCE & N & $\%$ \\
\hline Students & 176 & 63.1 \\
Teachers & 82 & 29.4 \\
Family & 3 & 1 \\
School Community & 16 & 5.7 \\
Administration & 1 & 0.4 \\
Others & 1 & 0.4 \\
\hline TOTAL & 279 & 100 \\
\hline
\end{tabular}


Regarding the procedures carried out by the educational SLH therapists, it was verified that the great majority of the research used the schools as the settings where they collected the data that referred mainly to assessment and diagnosis. In this regard, only $13 \%$ of the articles comprising the corpus of this study are related to the description and/or analysis of the intervention approaches, as seen in Figure 4.

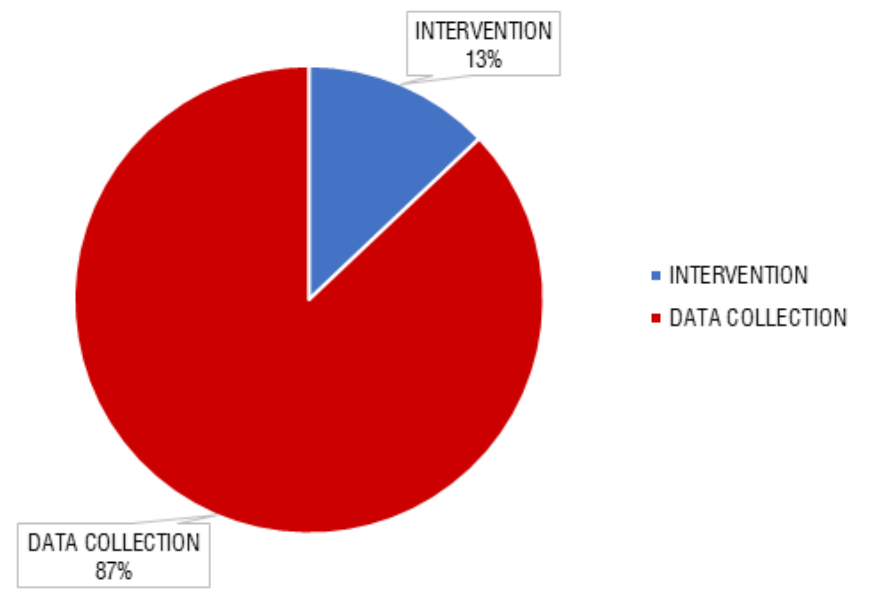

Figure 4. Procedures performed by speech-language-hearing therapists in educational institutions, distributed into two categories: data collection (assessment and diagnosis) and intervention

According to the CFFa, the educational SLH therapist can work in a school with training, advice and planning; developing SLH programs and putting them into action; observing and screening from the SLH standpoint; instructing on the use of language, oral-motor functions, hearing and voice; initiatives in the school setting that lead to conditions adequate to the teaching-learning process; contributions to the planning of pedagogical practices of the educational institutions ${ }^{6}$. Therefore, the amplitude and diversity of actions an SLH therapist can perform in partnership with the educational field are undeniable. Nonetheless, this study's result may reveal that this wide range of possibilities, while it seems to be neglected by the SLH therapist - to the extent that most of the research dealt with one specific pubic, with one specific type of action -, seems also be used to justify the SLH therapist's entrance into the school environment in a reductionist way, as they seem to consider the school only as research setting, not an action field.
Thus, it was observed that there was a greater amount of research conducted in educational institutions regarding the field of language, with elementary and middle school students. And, agreeing with a previous research ${ }^{1}$, it was observed that a great part of the studies dealt with the diagnosis and/or assessment of communication disorders, even when performed in a school setting ${ }^{1}$.

It is worth recalling that throughout history the school has been considered a privileged place for the prevention and correction of linguistic errors, and the $\mathrm{SLH}$ therapist arose as a professional due to the need to assess, diagnose and treat the language deviations manifested mainly within the educational institutions ${ }^{7,8}$. It is understood, then, that the findings exposed here are likely rooted in the very history of how the SLH sciences arose in Brazil. Therefore, they are influenced by its perception of health as restricted and traditional, giving priority to the twofold normal/pathological and health/disease approaches ${ }^{9,10}$.

Another factor that justifies a greater amount of research conducted in the field of language is its predominance in the registered complaints and the demand for SLH services ${ }^{11,12}$. A study about the mapping of Brazilian educational SLH therapists ${ }^{3}$ observed that preschool and elementary school count with the greatest concentration of such practitioners. This fact is probably associated with the process of learning literacy, a crucial developmental step in the initial stage of school life that brings concern to the whole educational community ${ }^{13}$.

Nevertheless, it is highlighted that the educational SLH therapist should not focus his work only on the pathological aspects of the students. Instead, they should favor health and learning in partnership with every member of the educational community, contributing to the improvement of oral and written communication, in the voice, speech, hearing and language patterns ${ }^{8,10}$. Currently, there tends to a discreet inclination towards a practice based on less restricted concepts - with a comprehensive perception of the subjects and their health, which is dependent on integrating various factors (social, economic, personal, etc. $)^{10}$.

In the last years, SLH therapy's work in partnership with education has been growing. Therefore, they are presently more solidly aware of the need to develop initiatives aimed at promoting health and learning among all subjects involved in the school setting (students, teachers, staff and parents) ${ }^{14}$. In this sense, 
it is emphasized that, although the partnership between SLH therapy and education is still based on physiciancentered concepts and the normal/pathological dichotomy, it is necessary to invest in broader actions that consider the school as more than a place where SLH alterations manifest and/or take place.

One of the roles of an educational SLH therapist is to conduct and publicize scientific research that contributes to the improvement of the quality of education and to consolidate their practice in the educational setting ${ }^{15}$. Hence, the fact that the number of studies conducted in this field is dropping calls attention, despite the educational SLH therapist's increasing presence in the educational context. Such a fact can suggest that their practice, besides being restricted to one specific public and still reductionist in its goals, may be walking toward (or persisting in) an intuitive work, little based on scientific evidence.

Furthermore, it is necessary to reflect on how the SLH therapist has been using educational institutions with research purposes. The data reveal the immense predominance of studies that use the school as a field to collect data, but few intend to analyze this professional's work and action in such settings.

Some studies ${ }^{16,17}$ already point out that the educators' perspective of educational SLH therapists is that of a practitioner with a clinical profile, who acts specifically on communication disorders, especially when these are related to the students. Analyzing the general data collected in this research may lead to the belief that such perspectives are brought to the schools by the SLH therapists themselves. Going to a school only to collect data about difficulties, pathologies and alterations - admittedly a legitimate SLH therapist's practice - eventually limits their working possibilities, which consequently leads to their not being valued as professionals in the educational context.

It is necessary to ponder upon the possibility of changing the conceptions and practices that are being left behind. Reconsidering the SLH therapist's practice with a critical eye in partnership with educational institutions can bring about new progress in this field, broadening the working possibilities and improving the effectiveness of the practices proposed by this professional.

It is further emphasized that the school must no longer be seen by the SLH therapist as an autonomous and independent entity, responsible for teaching standard written language, a setting ready for data to be collected. Beyond that, the educational institutions can and should be perceived as places subject to social contradictions, an integral part of the different ongoing social projects in our country, and therefore a stage where records are to be made ${ }^{18}$. This presupposes the acknowledgment of established articulations between the different areas, as the fields of education and health, and the material and subjective forms of organization in our society ${ }^{19}$.

\section{CONCLUSION}

Most of the national SLH research conducted in educational institutions favor practices in the fields of language and voice, with elementary school students as their predominant target audience.

Such practices mostly have the goal of identifying alterations and/or conducting preventive actions, based on perceptions that eventually dismiss the sociohistorical and cultural issues that overlap with the teaching-learning processes. Thus, the educational SLH therapist's work can still be considered a restricted one.

It is necessary to conduct initiatives and research that, once performed in educational institutions, would privilege educational aspects to the detriment of a focus exclusively on alterations and/or pathologies. It is believed that this is an important aspect to strengthen the field towards the broadening and acknowledgment of the educational SLH therapist's practice.

\section{REFERENCES}

1. Berberian AP, Ferreira LP, Jacob LC, Azevedo JBM, Mendes JM. A produção de conhecimento em Distúrbios da Comunicação: análise de periódicos (2000-2005). Rev Soc Bras Fonoaudiol. 2009;14(2):153-9.

2. Conselho Federal de Fonoaudiologia. Resolução № 387, 18 de setembro de 2010. Dispõe sobre as atribuições e competências do profissional especialista em Fonoaudiologia Educacional reconhecido pelo Conselho Federal de Fonoaudiologia, altera a redação do artigo 1 ㅇ da Resolução CFFa no 382/2010, e dá outras providências. Brasília; 2010.

3. Celeste LC, Zanoni G, Queiroga B, Alves LM. Hearing and Speech Sciences in educational environment mapping in Brazil: education, work and professional experience. CoDAS. 2017;29(1):e20160029. 
4. Tomaz-Morais JF, Lima JAS, Lucena BTL, Batista AUD, Limeira RRT, Silva SM et al. Integral analysis of Brazilian scientific production in Orofacial Myology: state of art and future perspectives. Rev. CEFAC. 2016;18(2):520-32.

5. Ercole FF, Melo LS, Alcoforado CLGC. Integrative review versus systematic review. Rev. Min Enferm. 2014;18(1):9-11.

6. Conselho Federal de Fonoaudiologia. Resolução № 309, 01 de abril de 2005. Dispõe sobre a atuação do Fonoaudiólogo na educação infantil, ensino fundamental, médio, especial e superior, e dá outras providências. Brasília; 2005.

7. Berberian AP. Fonoaudiologia e Educação: Um encontro histórico. 2a Ed. São Paulo: Plexus; 2007.

8. Conselho Regional de Fonoaudiologia - CRFa. 2a Região. Fonoaudiologia na Educação: Políticas Públicas e atuação do Fonoaudiólogo. São Paulo; 2010.

9. Berberian AP, Calheta PP. Fonoaudiologia e Educação: sobre práticas voltadas à formação de professores. In: Fernandes FDM, Mendes B, Navas AL (orgs). Tratado de Fonoaudiologia. 2a ${ }^{\underline{a}}$ ed. São Paulo: Roca; 2010. p. 682-91.

10. Lima ILB, Delgado IC, Lucena BTL, Figueiredo LC. Contributions of the institutional diagnosis for speech-language pathology and audiology practice in schools. Distúrb Comun. 2015;27(2):213-24.

11. Barros PML, Oliveira PN. Perfil dos pacientes atendidos no setor de fonoaudiologia de um serviço público de Recife - PE. Rev. CEFAC. 2010;12(1):128-33.

12. Diniz RD, Bordin R. Demanda em Fonoaudiologia em um serviço municipal da região sul do Brasil. Rev Soc Bras Fonoaudiol. 2011;16(2):126-31.

13. Queiroga B. Bons motivos para investirmos na Fonoaudiologia Educacional. In: Queiroga BAM, Zorzi JL, Garcia V (orgs). Fonoaudiologia Educacional: reflexões e relatos de experiência. Brasília: Editora Kiron; 2015. p. 44-53.

14. Giroto CRM. O professor na atuação fonoaudiológica em escola: participante ou mero espectador? In: Giroto CRM (org). Perspectivas atuais da fonoaudiologia na escola. São Paulo: Plexus Editora; 2001. p. 24-41.

15. Conselho Federal de Fonoaudiologia. Atuação do Fonoaudiólogo Educacional: Guia Norteador. Brasília; 2016.

16. Moura TFOR, Maldonade IR. Teachers and health team's view of the performance of speech-language therapy's role in early childhood education. Distúrb Comun. 2018;30(3):440-53.

17. Figueiredo L, Lima ILB, Silva HSE. Representations of educational professionals for speech-language and hearing sciences practice in schools. Disturb. Comunic. 2018;30(1):186-93.

18. Figueiredo LC. O outro na escola: algumas representações a respeito das diferenças [Tese]. Campinas (SP): Universidade de Campinas Unicamp; 2015.

19. Bortolozzi KBB. Fonoaudiologia e Educação: a constituição de uma parceria responsiva ativa [Tese]. Curitiba (PR): Universidade Tuiuti do Paraná - UTP; 2013. 